\title{
Determination of threshing and separation unit performance of rosemary (Rosmarinus officinalis) plants
}

\author{
Deniz Yilmaz ${ }^{*}$ Mehmet Emin Gökduman \\ (Department of Agricultural Machinery \& Technology Engineering, Faculty of Agriculture, Isparta University of Applied Sciences, \\ Isparta, Turkey)
}

\begin{abstract}
Rosemary (Rosmarinus officinalis L.) is an important perennial medicinal and aromatic plant belonging to the Lamiaceae family. Rosemary is widely produced in Turkey for its oil which can be extracted from the plants when flowers are in buds. In Turkey, a significant amount of domestic and foreign trade of rosemary is conducted. In 2018-2020, $2088 \mathrm{t}$ of rosemary plants were imported, while in the same years $2077 \mathrm{t}$ were exported. In this study, the performance indexes of a threshing and separating unit designed according to the physicomechanical properties of the rosemary were determined. The operating parameters of the machine were determined at three different moisture contents and adjusted according to the harvest moisture values. The threshing efficiency, work efficiency, power requirement, and specific energy consumption values of the threshing unit were determined, while separating efficiency, work efficiency and specific power consumption of separating unit of the developed system were determined. According to the study results, the threshing efficiency of the rosemary plant varied between $44.00 \%$ and $96.97 \%$. Work efficiency of the thresher varied between 1.18 and $15.34 \mathrm{~kg} / \mathrm{h}$. Power requirements and specific energy consumption of the threshing unit were obtained as $0.19-1.05 \mathrm{~kW}$ and $0.02-0.37 \mathrm{~kW} \cdot \mathrm{h} / \mathrm{h}$, respectively. On the other hand, the separating efficiency of the separating unit for the rosemary plant varied between $44.27 \%$ and $85.24 \%$. Maximum and minimum values of work efficiency were found as $0.75 \mathrm{~kg} / \mathrm{h}$ and 5.52 $\mathrm{kg} / \mathrm{h}$. Specific power consumption of the unit ranged from 3.95 to $39.95 \mathrm{~kW} / \mathrm{kg}$.
\end{abstract}

Keywords: rosemary, mechanization, threshing, separating, design, Turkey

DOI: $10.25165 /$ j.ijabe.20211406.6461

Citation: Yilmaz D, Gökduman M E. Determination of threshing and separation unit performance of rosemary (Rosmarinus officinalis) plants. Int J Agric \& Biol Eng, 2021; 14(6): 237-243.

\section{Introduction}

Rosemary is an aromatic perennial shrub native to the coasts of the Mediterranean Sea. The plant has narrow, thin, glossy, scented leaves. The plant stem is woody, resinous, and has a bitter taste ${ }^{[1]}$ Rosemary (Rosmarinus officinalis L.) is currently a widely used aromatic and medicinal plant. Many countries meet the needs of rosemary by harvesting from natural plants. In Turkey, rosemary collected from the natural flora of Mersin and Adana is presented to markets ${ }^{[2]}$. The rosemary is a strong aromatic plant using pharmaceutical industry due to its antioxidant and antimicrobial properties ${ }^{[3,4]}$. Rosemary has been used extensively as a source of strong antioxidant, antibacterial, antimutagenic properties and natural bioactive compounds. The antioxidant activity of rosemary is used in a wide array of applications, including food preservation. The plant leaves are also used as a condiment in food or flavoring of food products ${ }^{[5,6]}$. Although the use of fresh rosemary is not very common, dry rosemary forms are widely used in the food industry ${ }^{[7]}$.

Different properties of the rosemary increase its importance, and essential oils, plant extracts and some isolated components are subjected to some pharmacological research. Among the plants

\section{Received date: 2021-01-18 Accepted date: 2021-06-15}

Biographies: Mehmet Emin Gökduman, PhD candidate, Research Assistant, research interest: combine harvester, agriculture machinery, harvesting technology, Email: mehmetgokduman@isparta.edu.tr.

*Corresponding author: Deniz Yilmaz, $\mathrm{PhD}$, Professor, research interest: combine harvester, harvesting technology, agriculture machinery. Department of Agricultural Machinery \& Technology Engineering, Isparta University of Applied Sciences, Isparta, Turkey. Tel: +90-532-5683778, Email: denizyilmaz@isparta.edu.tr. reported to have antioxidative activity rosemary is the most widely used and commercialized ${ }^{[8-10]}$.

Rosemary plant, "rosemary oil" is grown for the aromatic oil and obtained by distillation of the plant leaves and flowers ${ }^{[11]}$. Rosemary (Rosmarinus officinalis L.) is a sempervirent, branched shrub with stiff stems, whitish-blue flowers and small dark green leaves at the back (Figure 1) ${ }^{[12]}$. It grows wildly along the northern and southern coasts of the Mediterranean, as well as in the Himalayan sub-regions ${ }^{[11]}$.

It can be exposed to various types of mechanical loads during harvest and post-harvest operations such as transportation, packaging, storage, and this causes significant damage and losses ${ }^{[13,14]}$. In particular, crop damage can occur during the harvest, transport and threshing processes of the rosemary plant ${ }^{[15]}$. Bai et al. ${ }^{[16]}$ conducted a study to determine the optimal settings and performance tests of the crop sections of the sugarcane chopper harvester. $\quad \mathrm{Du}$ et al. $^{[17]}$ designed a hand-held oil-tea fruit harvesting machine that can be operated by workers in hilly areas and carried out field experiments using the developed comb-brush harvesting machine. Huang et al ${ }^{[18]}$ has carried out the research and development of a small hemp harvester based on the absorption of domestic and foreign advanced technology of hemp harvester and conducted the field experiment of the machine. Some problems are confronted in the harvesting and post-harvesting stages of cultivation. These problems occur as the product is not threshing completely at high moisture contents or the product is poured quickly at very low moisture contents ${ }^{[19,20]}$. In order to reduce these problems, it is necessary to machine the threshing and separating works and to determine the optimum working conditions of the machine for the rosemary plant. 

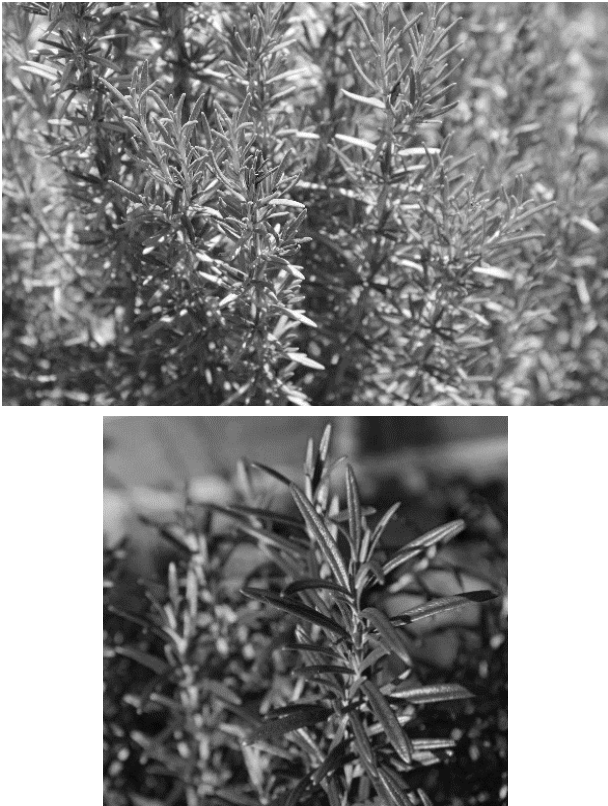

Figure 1 Rosemary plants

When the studies on this subject are researched, the threshing and separation of rosemary are usually made by human power. No machine has been found that performs threshing and separating processes at the same time. For this reason, the innovative aspect of this work is quite high. In this study, the working parameters and system performance of the threshing and separating machine for rosemary were determined.

\section{Materials and methods}

As a result of the preliminary tests, the working intervals of the machine for the rosemary plant were measured. Factor and level values were determined according to these values and a trial plan was created.

The experiments were performed at three different moisture contents $(8.9 \%, 12.0 \%$, and $14.8 \%)$, three different drum speeds (100 r/min, $250 \mathrm{r} / \mathrm{min}$, and $400 \mathrm{r} / \mathrm{min}$ ), three different drums clearances $(14,15$, and $16 \mathrm{~mm})$ and three different feed rates $(190 \mathrm{~kg} / \mathrm{h}, 380 \mathrm{~kg} / \mathrm{h}$, and $570 \mathrm{~kg} / \mathrm{h})$ for the threshing efficiency. The system was conducted at three different sieve types ( $2 \mathrm{~mm}$ round hole, $6 \mathrm{~mm}$ round hole and 4-20 oblong sieve), three different feedings $(190 \mathrm{~kg} / \mathrm{h}, 380 \mathrm{~kg} / \mathrm{h}$, and $570 \mathrm{~kg} / \mathrm{h})$, three different sieve oscillating frequencies $(35 \mathrm{~mm}, 40 \mathrm{~mm}$, and $45 \mathrm{~mm}$ ) and three different sieve slopes $(14.0 \%, 15.8 \%$, and $17.6 \%)$ for the separating efficiency. Each experiment was carried out with three replications. The experiment design was randomized blocks.

The performance tests of the machine, built for the rosemary were carried out at the harvest laboratory in Isparta Applied Science University, Turkey. The machine manufacturing picture was shown in Figure 2. The rosemary plants used in this study were harvested from the experimental field and dried after harvesting to the desired moisture content ${ }^{[13]}$.

Moisture content is an important factor in determining threshing efficiency ${ }^{[18]}$. As a result of preliminary tests, the moisture range of the plant was determined.

The experiments conducted for threshing performance were carried out at three different moisture contents as $8.9 \%, 12 \%$ and $14.8 \%$ dry basis (d.b).

Moisture content is not an effective factor for separation experiments, unlike threshing. Fixed moisture content can be chosen $^{[21]}$. For this reason, the moisture content of the materials was chosen as $12 \%$ in separation performance experiments. The rosemary plant, the drying time of which was determined in preliminary tests for the desired moisture value, was dried with a mechanical dryer available in the faculty laboratory. The moisture content of the rosemary plant has reached the desired level in $4 \mathrm{~h}$.

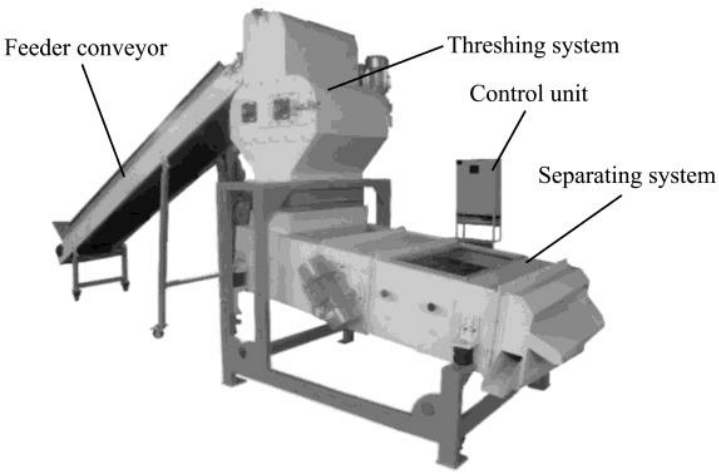

Figure 2 Rosemary threshing and separation machine

\subsection{Threshing unit}

Rasp-type drums are used more particularly in combine harvesters thanks to the crushing and scrubbing effects. The beaters need to be separate leaves from the stalk. Therefore, a rasp bar type of drum has been chosen for the threshing system. Eight sheet bars $(35 \mathrm{~mm} \times 10 \mathrm{~mm})$ were attached to the drum and covered with hard rubber. There are two drums with $770 \mathrm{~mm}$ in length and $136 \mathrm{~mm}$ in diameter in the threshing units. Two beaters can rotate in the same or opposite directions. The product entering the threshing unit from the conveyor is dropped the separating unit pass through the drums. The torque meter mounted to the motor shaft is calculated as the torque value and the power consumed by the threshing unit (Figure 3).

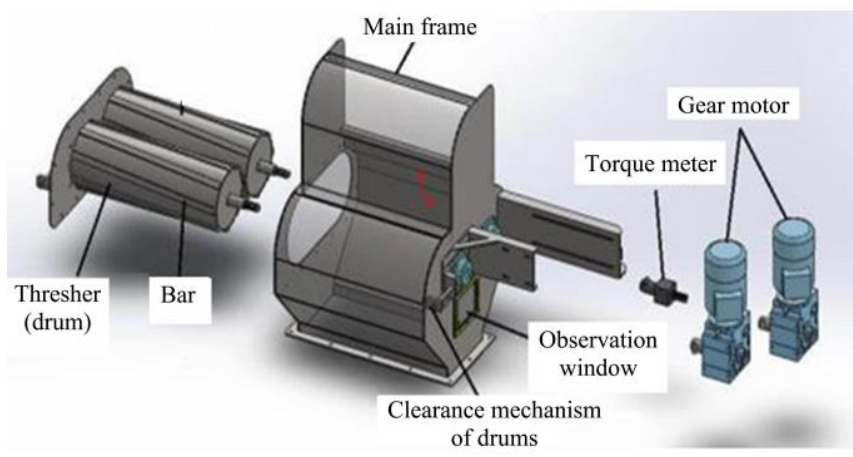

Figure 3 Rosemary threshing unit

In the course of determining threshing unit performance threshing efficiency, seed damage, unbroken capsule percentage, specific energy consumption and power requirement were used ${ }^{[22]}$.

The amount of the product to feed the threshing unit in each experiment was specified as $190 \mathrm{~kg} / \mathrm{h}, 380 \mathrm{~kg} / \mathrm{h}, 570 \mathrm{~kg} / \mathrm{h}$. The feeding unit speed was $0.26 \mathrm{~m} / \mathrm{s}$. The drum speeds of threshing units were determined as $100 \mathrm{r} / \mathrm{min}, 250 \mathrm{r} / \mathrm{min}$, and $400 \mathrm{r} / \mathrm{min}$ $(1.48 \mathrm{~m} / \mathrm{s}, 3.69 \mathrm{~m} / \mathrm{s}$, and $5.55 \mathrm{~m} / \mathrm{s})$. The working properties of the rosemary threshing unit were shown in Table 1. These operating parameters were determined according to the capacity of the machine and preliminary trials.

Table 1 Working properties of the rosemary threshing unit

\begin{tabular}{cccc}
\hline & Threshing drum speed $/ \mathrm{r} \cdot \mathrm{min}^{-1} ; \mathrm{m} \cdot \mathrm{s}^{-1}$ & Drums clearance/mm \\
\hline \multirow{3}{*}{ Drum 1 } & Experiment 1 & $100 ; 1.48$ & 14 \\
& Experiment 2 & $250 ; 3.69$ & 15 \\
& Experiment 3 & $400 ; 5.55$ & 16 \\
\hline \multirow{2}{*}{ Drum 2 } & $35 ; 0.45$ \\
\hline
\end{tabular}




\subsection{Separating unit}

The separating unit of the system consists of chassis, mainframe, vibrating sieves, slope adjusting mechanism and material outlet unit (Figure 4). Sieves and eccentrics were used in parallel with developing technologies in the separation system. The duration of the material on the sieve, sieve type, material amount and sieve slope are important parameters for separation efficiency $^{[23]}$.

For the separating, to the rosemary plant, three different sieves as $6 \mathrm{~mm}$ round hole, $2 \mathrm{~mm}$ round hole and 4-20 oblong sieves chosen in the preliminary test were used in the experiments. Feeding unit speed was determined as $0.26 \mathrm{~m} / \mathrm{s}$. Separating efficiency, work efficiency and specific power consumption of separating unit developed were determined.

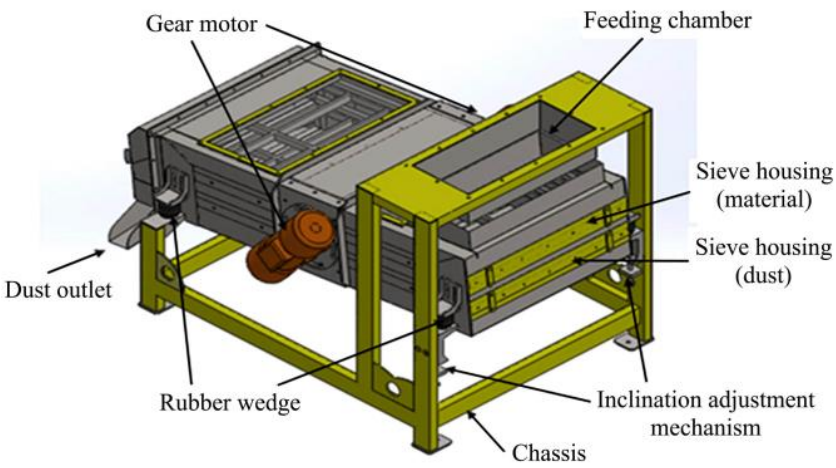

Figure 4 Rosemary separating unit

The amount of the product for feeding the separating unit was the same with the threshing experiments as $190 \mathrm{~kg} / \mathrm{h}, 380 \mathrm{~kg} / \mathrm{h}$, $570 \mathrm{~kg} / \mathrm{h}$. The sieve oscillating frequencies of the unit were chosen as $35 \mathrm{~Hz}, 40 \mathrm{~Hz}$, and $45 \mathrm{~Hz}$ for the experiments. The working properties of the rosemary-separating unit were shown in Table 2. These operating parameters were determined according to the capacity of the machine and preliminary trials.

Table 2 Working properties of the rosemary separating unit

\begin{tabular}{ccc}
\hline Serial number & Sieve oscillating frequency/Hz & Sieve inclination/\% \\
\hline Experiment 1 & 35 & 14.0 \\
Experiment 2 & 40 & 15.8 \\
Experiment 3 & 45 & 17.6 \\
\hline
\end{tabular}

The following equations were used to calculate the threshing efficiency (TE) and work efficiency (WE) of the machine ${ }^{[21]}$

$$
\mathrm{TE}=\frac{P_{t}}{P_{t}+P_{u}}
$$

where, TE is the threshing efficiency, $\% ; P_{t}$ is the threshed product, $\mathrm{kg} ; P_{u}$ is the unthreshed product (leaves in straws), $\mathrm{kg}$.

The following equation is used in the calculation of the separating efficiency of the machine.

$$
\mathrm{SE}=\frac{P_{s}}{P_{s}+P_{u}}
$$

where, SE is the separating efficiency, $\% ; P_{s}$ is the separated product, $\mathrm{kg} ; P_{u}$ is the unseparated product (leaves in straws), $\mathrm{kg}$.

\section{Results and discussion}

\subsection{Threshing unit performance}

The efficiency values of the threshing unit varied between $44.03 \%$ and $96.97 \%$. The effects of drums clearance, feed rate and drum speed on the threshing efficiency were given in Figure 5. As a result of the experiment carried out depending on the Lavandin's moisture content, drum distance, feed rate and drum speed of the machine threshing efficiency values ranged from $45.69 \%$ to $95.56 \%{ }^{[21]}$. Depending on the moisture content of the sage, drums distance, feeding rate and drum speed of the machine, the threshing efficiency values of the system varied between $48.92 \%$ and $94.58 \%$ d.b. ${ }^{[25]}$

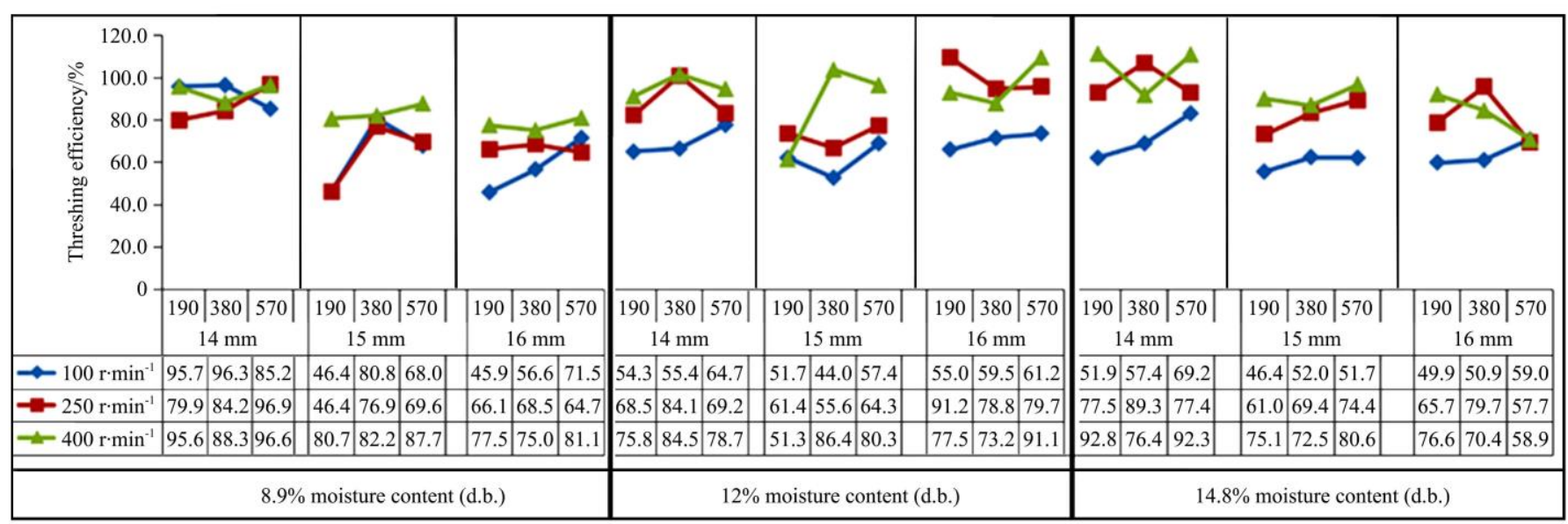

Note: The value in each cell indicates average threshing efficiency values according to the drums distance, feed rate and drum speed.

Figure 5 Threshing efficiency values of rosemary thresher

According to the result of the performance experiments of the machine, the threshing efficiency was decreased while the moisture content was increased. The interactions of drums clearance $\times$ feed rate $\times$ drum speed on the efficiency of the threshing unit at $8.9 \%$, $12 \%$ and $14.8 \%$ d.b. moisture contents were found statistically significant $(p<0.05)$. The highest value of the efficiency was calculated as $96.97 \%$ at $8.90 \%$ d.b. moisture content, $14 \mathrm{~mm}$ drums clearance, $250 \mathrm{r} / \mathrm{min}$ drum speed and $570 \mathrm{~kg} / \mathrm{h}$ feed rate. The lowest efficiency of the machine was calculated as $44.03 \%$ d.b at $12 \%$ d.b. moisture content, $15 \mathrm{~mm}$ drums clearance, $100 \mathrm{r} / \mathrm{min}$ drum speed and $380 \mathrm{~kg} / \mathrm{h}$ feed rate. The effects of drums clearance $\times$ feeding rate $\times$ drum speed on the work efficiency were shown in Figure 6.

The work efficiency was decreased with increasing moisture content. The interactions of drums clearance $\times$ feed rate $\times$ drum speed on the work efficiency at different moisture contents were found statistically significant $(p<0.05)$. The highest efficiency values were reached for rosemary with the thresher operating parameters adjusted as $14 \mathrm{~mm}$ drums clearance, $400 \mathrm{r} / \mathrm{min}$ drum speed and $570 \mathrm{~kg} / \mathrm{h}$ feed rate. The highest and lowest work efficiency values were determined as $1.18 \mathrm{~kg} / \mathrm{h}$ and $15.34 \mathrm{~kg} / \mathrm{h}$ at $14.3 \%$ moisture content. In the study conducted by Bai et al. ${ }^{[16]}$, 
the threshing efficiency value was found between 0.67 and $12.27 \mathrm{~kg} / \mathrm{h}$ for lavandin. The work efficiency values ranged from 1.43 to $11.87 \mathrm{~kg} / \mathrm{h}$ for sage plants ${ }^{[25]}$.

The power requirement of the threshing unit of the machine needs to be calculated for system performance. The effects of drums clearancexfeed ratexdrum speed on the power requirement were shown in Figure 7.

The power requirement values of the threshing unit for the rosemary plant varied between 0.19 and $1.05 \mathrm{~kW}$. The power requirement values of the lavandin threshing unit, depending on the moisture content, drums distance, feeding rate and drum speed of the threshing unit, varied between 0.200 and 1.081 $\mathrm{kW}^{[24]}$. The triple interaction of drums clearance $\times$ feed rate $\times$ drum speed on the power requirement was found statistically significant $(p<0.05)$. The power requirement of the thresher was decreased up to $12 \%$ moisture content. The values increased by increasing the moisture content of the plants to $14.8 \%$. While the highest values were obtained at the same drums clearance, $400 \mathrm{r} / \mathrm{min}$ drum speed and $570 \mathrm{~kg} / \mathrm{h}$ feed rate, the lowest power requirement values were determined with the parameters of $14 \mathrm{~mm}$ drums clearance, $100 \mathrm{r} / \mathrm{min}$ drum speed and $190 \mathrm{~kg} / \mathrm{h}$ feed rate.

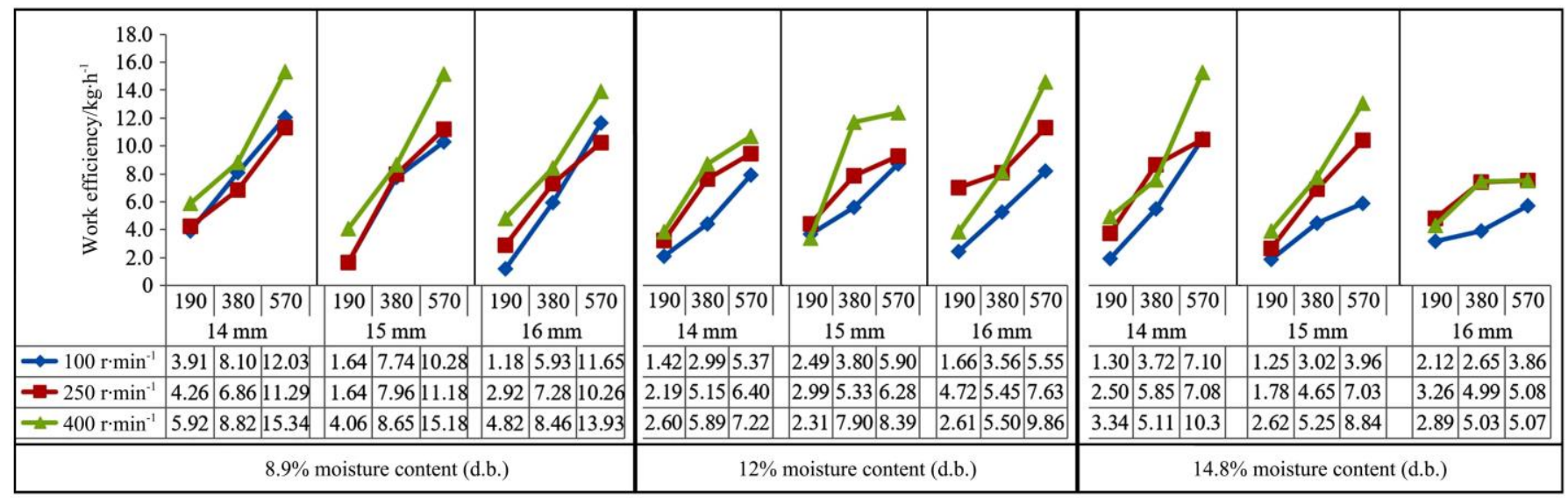

Note: The value in each cell indicates average work efficiency values according to the drums distance, feed rate and drum speed.

Figure 6 Work efficiency values of rosemary threshing unit

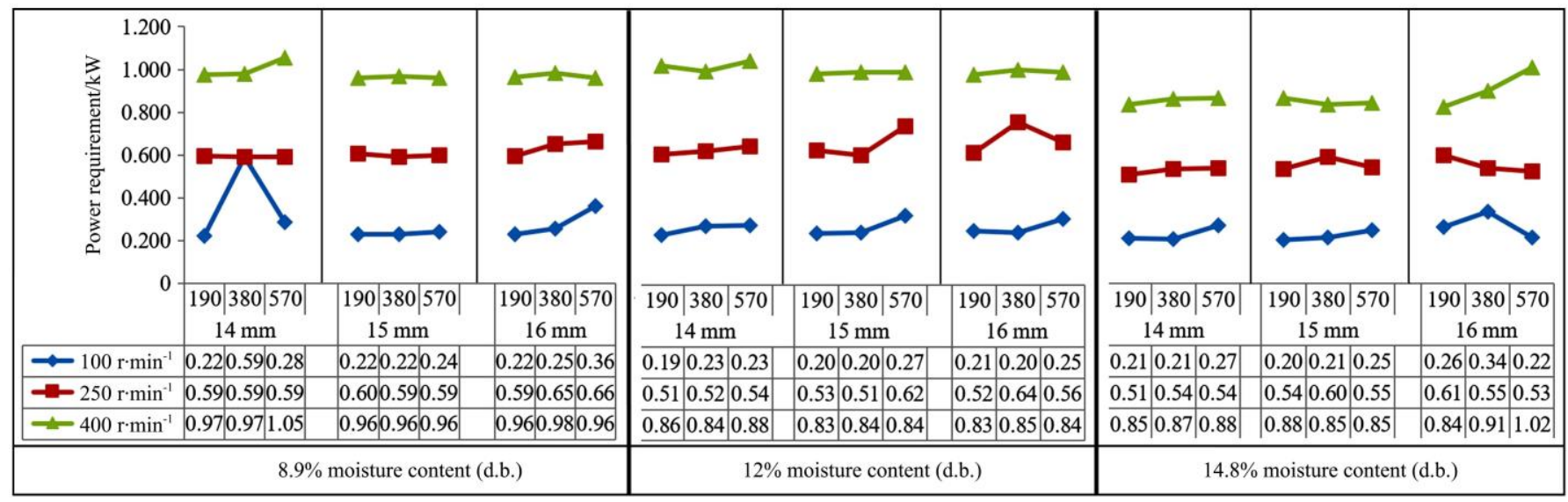

Note: The values in each cell indicate average power requirement values according to the drums distance, feed rate and drum speed.

Figure 7 Power requirement values of rosemary threshing unit

According to the results, the specific energy consumption of the threshing machine was increased with increasing moisture content. The specific energy consumption values of the threshing unit were found between 0.02 and $0.37 \mathrm{~kW} \cdot \mathrm{h} / \mathrm{kg}$ (Figure 8), while they were ranged from 0.03 to $0.59 \mathrm{~kW} \cdot \mathrm{h} / \mathrm{kg}$ for lavandin plant ${ }^{[24]}$. On the other hand, values of the threshing unit performed for the sage plant were found between 0.028 and $0.534 \mathrm{~kW} \cdot \mathrm{h} / \mathrm{kg}^{[25]}$.

The interactions of drums clearance $\times$ feed rate $\times$ drum speed on the specific energy consumption were found statistically significant $(p<0.05)$. The highest values were observed at $12 \%$ moisture content. The lowest specific energy consumption of the machine was obtained at $8.9 \%$ moisture content. While specific energy consumption of the unit was lowest at $16 \mathrm{~mm}$ drums clearance, $570 \mathrm{~kg} / \mathrm{h}$ feed rate and $100 \mathrm{r} / \mathrm{min}$ drum speed, it was highest at $15 \mathrm{~mm}$ drums clearance, $190 \mathrm{~kg} / \mathrm{h}$ feed rate and $400 \mathrm{r} / \mathrm{min}$ drum speed.

\subsection{Separating unit performance}

The efficiency values of the separating unit of the system were ranged from $44.27 \%$ to $99.00 \%$. In the study conducted by Yilmaz et al. ${ }^{[26]}$, the separating efficiency was found between $41.44 \%$ and $97.49 \%$ for the sage plant. According to this study results the effect of sieve oscillating frequency, feeding rate and sieve inclination on the separating efficiency with different sieve types are shown in Figure 9.

As a result of the experiments the highest separating efficiency value was found at $15.8 \%$ sieve slope, $380 \mathrm{~kg} / \mathrm{h}$ feed rate and $45 \mathrm{~Hz}$ of sieve oscillating frequency with 4-20 oblong sieve type. The lowest separation efficiency was observed in experiments with a $2.0 \mathrm{~mm}$ hole sieve with a sieve inclination of $14.0 \%$, a feed rate of $380 \mathrm{~kg} / \mathrm{h}$ and a sieve rate of $40 \mathrm{~Hz}$. The triple interaction of sieve oscillating frequency, feed rate and sieve slope on separation efficiency with three different sieve types was statistically significant $(p<0.05)$. 
According to the results of the study carried out for rosemary plants, the interaction of sieve oscillating frequency, feed rate and sieve slope with the work efficiency values are shown in Figure 10.

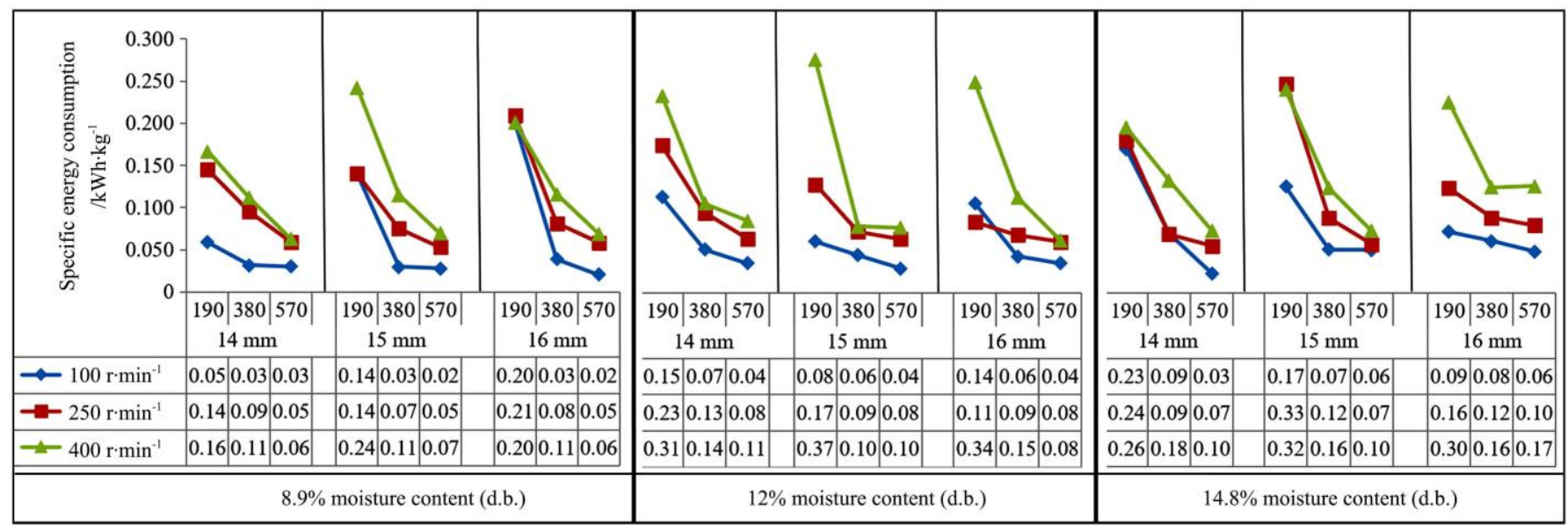

Note: The value in each cell indicates average specific energy consumption values according to the drums distance, feed rate and drum speed.

Figure 8 Specific energy consumption values of rosemary threshing unit

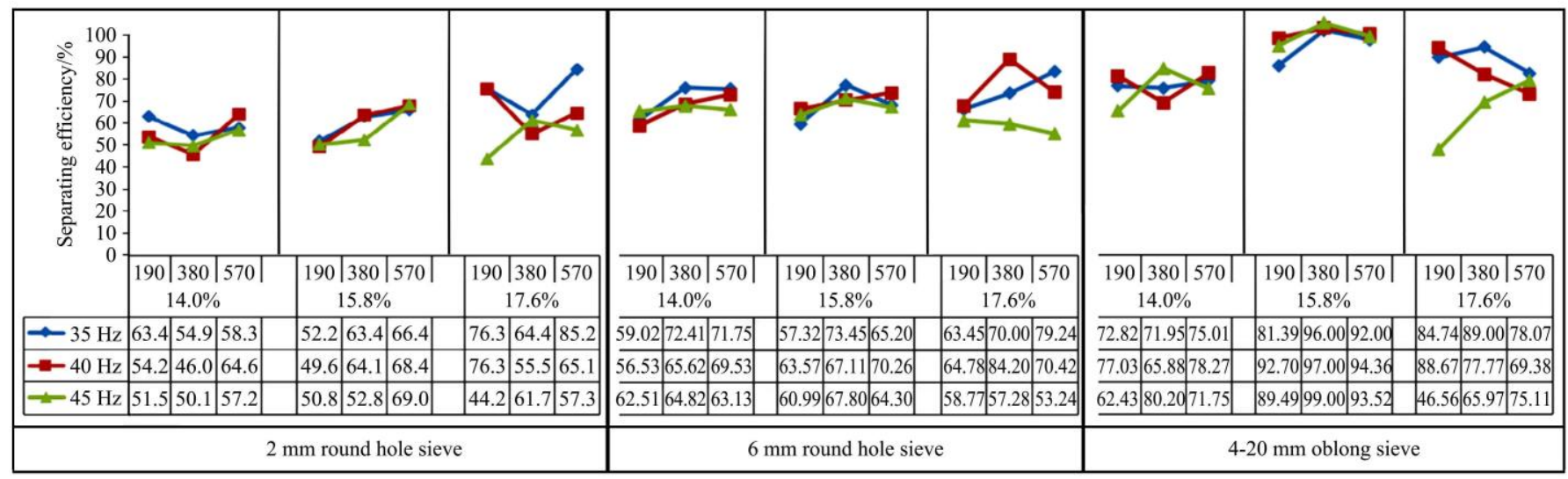

Note: The value in each cell indicates average separating efficiency values according to the sieve oscillating frequency, feed rate and sieve inclination.

Figure 9 Separating efficiency values of rosemary separating unit

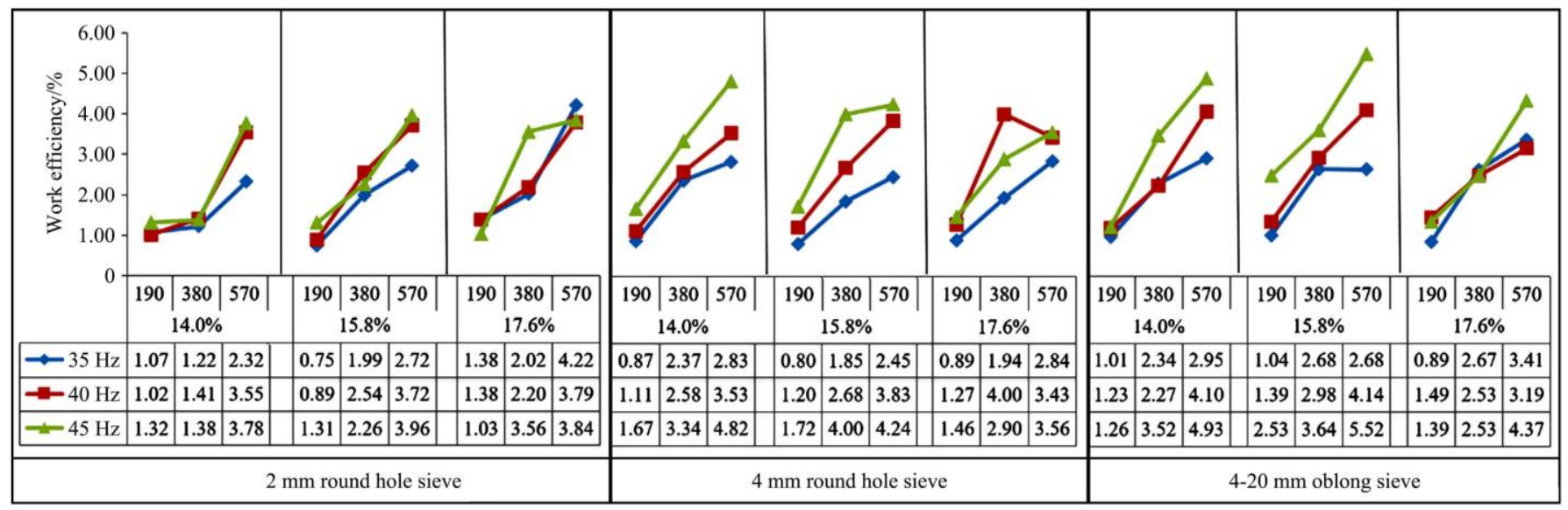

Note: The values in each cell indicate average work efficiency values according to the sieve oscillating frequency, feed rate and sieve inclination.

Figure 10 Work efficiency values of rosemary separating unit

According to the results of the experiments, the lowest work efficiency value was found as $0.75 \mathrm{~kg} / \mathrm{h}$ at $15.8 \%$ sieve inclination, $35 \mathrm{~Hz}$ sieve oscillating frequency and $190 \mathrm{~kg} / \mathrm{h}$ feeding rate in the Specific power consumption values for the system design must be determined and known for the system performance of the separation unit. The specific power consumption values of the separation unit for rosemary plants made with three different sieve types are given in Figure 11.

The specific power consumption values of the separating system varied between $3.95 \mathrm{~kW} / \mathrm{kg}$ and $39.95 \mathrm{~kW} / \mathrm{kg}$.

The triple interaction of speed, feed rate and sieve slope on the specific power consumption with three different sieves were found statistically significant $(p<0.05)$. While the specific power consumption of separating unit for rosemary plant was lowest at $570 \mathrm{~kg} / \mathrm{h}$ feeding rate and $35 \mathrm{~Hz}$ of sieve oscillating frequency, it was highest at $190 \mathrm{~kg} / \mathrm{h}$ feeding rate and $45 \mathrm{~Hz}$ sieve oscillating frequency. Each result was obtained from experiments performed with a $2 \mathrm{~mm}$ round hole sieve and $17.6 \%$ sieve inclination. 


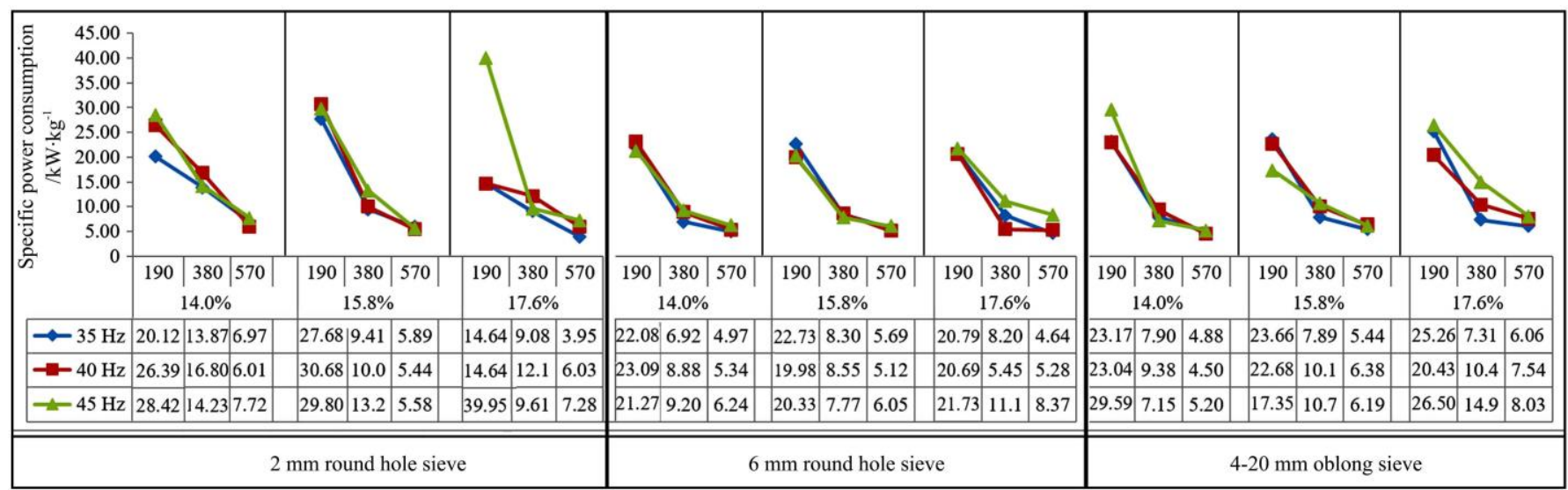

Note: The value in each cell indicates average specific power consumption values according to the sieve oscillating frequency, feed rate and sieve inclination.

Figure 11 Specific power consumption values of rosemary separating unit

\section{Conclusions}

When the machine is evaluated in terms of threshing efficiency, it is suggested to operate the threshing unit at $14 \mathrm{~mm}$ drums clearance, $570 \mathrm{k} / \mathrm{h}$ feed rate and $250 \mathrm{r} / \mathrm{min}$.

It should be recommended that for the proper work efficiency, the thresher can be operated 14 drums clearance, $570 \mathrm{~kg} / \mathrm{h}$ feed rate and $400 \mathrm{r} / \mathrm{min}$ drum speed.

The working parameters need to be adjusted as $14 \mathrm{~mm}$ drums clearance, $190 \mathrm{~kg} / \mathrm{h}$ feed rate and $100 \mathrm{r} / \mathrm{min}$ drum speed for the minimum power requirement.

The operating parameters of the threshing unit should be selected $16 \mathrm{~mm}$ drums clearance, $570 \mathrm{~kg} / \mathrm{h}$ feed rate and $100 \mathrm{r} / \mathrm{min}$ for the low specific energy consumption.

When the separating unit for the rosemary plant is evaluated in the way of separating efficiency and work efficiency, it has been recommended to operate the machine with 4-20 oblong sieve at $380 \mathrm{~kg} / \mathrm{h}$ feed rate, $45 \mathrm{~Hz}$ sieve oscillating frequency and $15.8 \%$ sieve slope.

The operating parameters of separating units were specified as $14.0 \%$ sieve slope, $570 \mathrm{~kg} / \mathrm{h}$ feeding rate and $35 \mathrm{~Hz}$ sieve oscillating frequency with $10 \mathrm{~mm}$ round-hole sieve.

From the result above, it is clear that the optimum operating parameters of the rosemary threshing unit to improve efficiency are $14 \mathrm{~mm}$ drums clearance and 250 or $400 \mathrm{r} / \mathrm{min}$ drum speed. On the other hand for the high yield, the separating parameters should be chosen as $17.6 \%$ sieve slope $40 \mathrm{~Hz}$ sieve oscillating frequency with 4-20 mm oblong sieve.

\section{Acknowledgements}

This work was supported a part of by the TUBITAK-3501-National Young Researchers Career Development Program (CAREER), and the Determination of Threshing and Separation System Parameters of Some Medicinal Aromatic Plants and Development of Prototype (Grant No. 1110179). The authors would like to acknowledge the TUBITAK for its contributions to the project conducted by Deniz Yilmaz.

\section{[References]}

[1] Sanabria B. Characterization física y fisiológica postcosecha de dos hierbas aromáticas condimentarias: cebollín (Allium shoenoprasum) y oregano (Origanum vulgare L.) a tres temperatures, almacenado con y sin empaque. Journal of Food Composition Analysis 2004; 19: 6-7.

[2] Kırıcı S, İnan M. Effect of different harvesting time on the essential oil content of Rosemary (Rosmarinus officinalis L.) in the Çukurova conditions. In: Özgüven M (Ed.). Proceedings of the Workshop on Agricultural and Quality Aspects of Medicinal and Aromatic Plants, 2002; pp.263-271. doi: 10.13140/RG.2.2.14874.70087.

[3] Bruneton J. Essential oils. Pharmacology: phytochemistry medicinal plants. 2nd ed. Paris: Intercept Ltd. 1999; 1136p.

[4] Bozin B, Mimica-Dukic N, Samojlik I, Jovin E. Antimicrobial and antioxidant properties of rosemary and sage (Rosmarinus officinalis $\mathrm{L}$. and Salvia officinalis L., Lamiaceae) essential oils. Journal of Agricultural and Food Chemistry, 2007; 55(19): 7879-7885.

[5] Che Man Y B, Tan C P. Effects of natural and synthetic antioxidants on changes in refined, bleached, and deodorized palm olein during deep - fat frying of potato chips. Journal of the American Oil Chemists' Society, 1999; 76(3): 331-339.

[6] Bensebia O, Allia, K. Analysis of adsorption-desorption moisture isotherms of rosemary leaves. Journal of Applied Research on Medicinal and Aromatic Plants, 2016; 3(3): 79-86.

[7] Hamre K, Kolås K, Sandnes K. Protection of fish feed, made directly from marine raw materials, with natural antioxidants. Food Chemistry, 2010; 119(1): 270-278.

[8] Cuvelier M E, Richard H, Berset C. Antioxidative activity and phenolic composition of pilot - plant and commercial extracts of sage and rosemary. Journal of the American Oil Chemists' Society, 1996; 73(5): 645-652.

[9] Yesilbag D, Eren M, Agel H, Kovanlikaya A, Balci F. Effects of dietary rosemary, rosemary volatile oil and vitamin $\mathrm{E}$ on broiler performance, meat quality and serum SOD activity. British Poultry Science, 2011; 52(4): 472-482.

[10] Draz W S A. The antibacterial potentials and synergistic effect of some plant extracts against multidrug resistant clinical pathogens. Islamic University-Gaza Deanship of Graduate Studies Biological Sciences Master Program, 2015; 181p.

[11] Tyler V E, Brady L R, Robbers J E. Pharmacognosy. Philadelphia, PA: Lea and Febiger, 1956, 520 p.

[12] Al-Sereiti M R, Abu-Amer K M, Sena P. Pharmacology of rosemary (Rosmarinus officinalis Linn.) and its therapeutic potentials. Indian Journal of Experimental Biology, 1999; 37(2): 124-130.

[13] Mohsenin N N. Physical properties of plant and animal materials (2nd ed. (revised)). New York: Gordon and Breach Science Publications, 1986; 891p.

[14] Singh K K, Reddy B S. Post-harvest physico-mechanical properties of orange peel and fruit. Journal of Food Engineering, 2006; 73(2): $112-120$.

[15] Arévalo C A, Castillo B, Londoño M T. Mechanical properties of rosemary (Rosmarinus officinalis L.) stalks. Agronomía Colombiana, 2013; 31(2): 201-207.

[16] Bai J, Ma S, Wang F, Xing H, Ma J, Hu J. Field test and evaluation on crop dividers of sugarcane chopper harvester. Int $\mathrm{J}$ Agric \& Biol Eng, 2021; 14(1): 118-122.

[17] Du X, Shen T, Zhao L, Zhang G, Hu A, Fang S, et al. Design and experiment of the comb-brush harvesting machine with variable spacing for oil-tea camellia fruit. Int J Agric \& Biol Eng, 2021; 14(1): 172-177.

[18] Huang J, Shen C, Ji A, Tian K, Zhang B, Li X, et al. Design and test of two-wheeled walking hemp harvester. International Journal of Agricultural and Biological Engineering, 2020; 13(1): 127-137. 
[19] Baydar H. Tibbi ve Aromatik Bitkiler Bilimi ve Teknolojisi (Genişletilmiş 3. Bask1). SDÜ Yayınları, 2009; 51: 194-212. (in Turkish)

[20] Ertuğrul M, Tarhan S. Effect of different drying air temperature profiles on drying kinetics of Melissa (Melissa officinalis L.) plant and energy consumption. Gaziosmanpasa Journal of Scientific Research, 2017; 6: 1-10.

[21] Güzel E. Hasat-Harman İlkeleri ve Makineleri. Ç.Ü. Ziraat Fakültesi Ders Kitabı. Adana: Çukuroava Üniversitesi Yayınları, 1998; 394p (in Turkish)

[22] Sudajan S, Salokhe V M, Triratanasirichai K. PM-Power and machinery: effect of type of drum, drum speed and feed rate on sunflower threshing. Biosystems Engineering, 2002, 83.4. 413-421.
[23] Kutzbach H D. Approaches for mathematical modelling of grain separation. In: International Conference on Crop Harvesting and Processing. ASABE, 2003; 64p.

[24] Yilmaz D, Gokduman M E. Determination of threshing performance of new design threshing unit for lavandin (Lavandula $\times$ intermedia Emeric ex Loisel.). In: Proceeding of 2018 World Congress of CIGR, Antalya: CIGR, 2018; pp.99-106.

[25] Yilmaz D, Gokduman M E. Determination of threshing performance of new design threshing unit for sage. Agronomy, 2018; 61(1): 218-222.

[26] Yilmaz D, Gokduman M E. Determination of separating performance of new design separating unit for sage. Agronomy, 2018; 61(2): 85-89. 